Research Paper

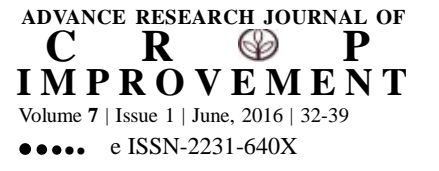

DOI :

10.15740/HAS/ARJCI/7.1/32-39

Visit us: www.researchjournal.co.in

\section{Synthesis of inorganic nanoparticles for the enhancement of seed quality in groundnut cV. VRI-2}

\author{
K. KRISHNA SHYLA AND N. NATARAJAN ${ }^{1}$
}

\begin{abstract}
The present study was carried out to assess seed quality parameters by using inorganic nanoparticles (NPs) viz., zinc oxide $(\mathrm{ZnO})$, silver $(\mathrm{Ag})$ and titanium dioxide $\left(\mathrm{TiO}_{2}\right)$ were synthesized by chemical method and characterized by using Scanning Electron Microscope (SEM) and Transmission Electron Microscope (TEM). Among the three nanoparticles, $\mathrm{ZnO}$ NPs possessed the least size of 35-45 nm, while the maximum of $100 \mathrm{~nm}$ was observed in $\mathrm{TiO}_{2}$ NPs. Fresh seeds of groundnut were treated with NPs of $\mathrm{ZnO}, \mathrm{Ag}$ and $\mathrm{TiO}_{2}$ each @ 750, 1000 and $1250 \mathrm{mg} \mathrm{kg}^{-1}$ of seed and stored for 12 months under ambient condition. After 12 months of storage, seeds treated with ZnO NPs @ $1000 \mathrm{mg} \mathrm{kg}^{-1}$ enhanced germination (77\%), vigour index (3067), electrical conductivity $\left(0.347 \mathrm{dSm}^{-1}\right)$, catalase $\left(0.421 \mu \mathrm{g} \mathrm{H}_{2} \mathrm{O}_{2} \mathrm{mg}^{-1} \mathrm{~min}^{-1}\right)$ enzyme activity and reduced lipid peroxidation activity ( 0.089 OD value) against the control $(66 \%, 2328,0.379$ $\mathrm{dSm}^{-1}, 0.385 \mu \mathrm{g} \mathrm{H}_{2} \mathrm{O}_{2} \mathrm{mg}^{-1} \mathrm{~min}^{-1}$ and $0.112 \mathrm{OD}$ value, respectively). The present investigation clearly demonstrated the effect of inorganic NPs of ZnO @ $1000 \mathrm{mg} \mathrm{kg}^{-1}$ and Ag @ $1250 \mathrm{mg} \mathrm{kg}^{-}$ ${ }^{1}$ of seeds in maintaining the quality of aged groundnut seeds.
\end{abstract}

\footnotetext{
Author for correspondence: K. KRISHNA SHYLA Department of Seed Science and Technology, Tamil Nadu Agricultural University, COIMBATORE (T.N.) INDIA Email: shylaja.agri@gmail.com
}

KEY WORDS : Synthesis of nanoparticles, SEM, TEM, Groundnut seed quality

How to cite this paper : Shyla, K. Krishna and Natarajan, N. (2016). Synthesis of inorganic nanoparticles for the enhancement of seed quality in groundnut cv. VRI-2. Adv. Res. J. Crop Improv., 7 (1) : 32-39, DOI : 10.15740/HAS/ARJCI/7.1/32-39.

Paper History : Received : 01.02.2016; Revised : 22.03.2016; Accepted : 26.04.2016 